\title{
Study on Export-oriented Enterprises' Improvement of Competitive Capacity Based on Cost Advantage
}

\author{
Xingwu Yu (Corresponding author) \\ Changzhou University \\ Changzhou 213164, Jiangsu, China \\ E-mail: dzyxw@163.com \\ Weixing Wang \\ Changzhou University \\ Changzhou 213164, Jiangsu, China
}

Received: October 1, $2010 \quad$ Accepted: November 16, $2010 \quad$ doi:10.5430/jms.v1n1p118

Foundation Item of Philosophical Social Science in Colleges and Universities of Jiangsu Province Office of Education (09SJD630022)

\begin{abstract}
For the past several years, cost advantage of production factors have always been the primary motive of export-oriented enterprises in China and important source of their competitive capacity. However, adverse changes are taking place in cost advantage of production factors for the time being. In-depth exploration of effective tactics in the aspects of technology, marketing and management to facilitate export-oriented enterprises to acquire new cost advantage and possess new competitive capacity will have quite important practical significance.
\end{abstract}

Keywords: Export-oriented enterprises, Cost advantage, Competitive capacity, Tactics

\section{Introduction}

Before the year 2006, the motive for development of export-oriented enterprises was mainly cost advantage in production factors, especially advantages in labor force cost, land use cost, tax incidence cost (such as export rebates), etc. However, afterwards, with rise of the price of raw material, appreciation of the RMB, implementation of the new Labor Contract Law, and changes of interest rates, exchange rate and export rebate rate as well as foreign technical barrier and green barrier, etc, the cost advantage of production factors which export-oriented enterprises had always been depending upon gradually faded away, while acquisition of cost advantage by virtue of technique, management and marketing is still lacking, so quite a large number of export-oriented enterprises have been trapped in the dilemma of operation. Although the export sales of China in 2009 surpassed Germany and jumped to take the first place in the world, lots of exports were just small profits and even without any profit, thus the economic profit was low. At present, the operation and management mode in a lot of export-oriented enterprises has not been changed and their competitive capacity is still low, so it is difficult for them to respond to the austere operation environment and foreign trade situation. In the current post-crisis era, how to enable the cost of an enterprise to become lower than that of its international competitor and expand due space for profits has been a realistic issue which all export-oriented enterprises are concerned with.

\section{Relationship between cost advantage and improvement of competitive capacity}

What export-oriented enterprises are faced up with is international competition, which involves such factors as technology, products, service, price, quality and brand and all these competitive factors can be summarized as whether the enterprises can acquire technical advantage and cost advantage. It is required that technical advantage need to have corresponding cost advantage, by which means the enterprises can obtain high economic interests and it is difficult for their competitors to simulate. In his "Competitive Strategy”, Michael E. Porter definitely put forward the concept of cost leadership strategy. Cost leadership strategy refers to the competitive strategy that when an enterprise offers products or service, its cost or expense is obviously lower than that offered by the average industrial level or its competitor's level. 
In cost leadership strategy, an enterprise gainsmore profits and accumulates more capital through cost advantage to possess stronger environmental adaptation capacity and improve its competitive capacity. Major means for an enterprise to acquire cost advantage include reconstruction of value chain activity and strict control over cost driver. Within an enterprise, the enterprise may conduct internal value chain activities more effectively than its competitors and more strictly control all cost drivers to create cost advantage. Outside the enterprise, the enterprise may reduce its industrial chain cost by reorganization of the value chain of upstream and downstream enterprises to acquire cost advantage. Re-integration of upstream and downstream enterprises in terms of technology, information, fund management and market resources, etc, can gather their core competence in different value chain links and realize economy and efficiency of cost input in research and development design, material purchase, processing and manufacturing, quality guarantee, product sales, customer service and payment collection, etc. Acquisition of long-term and stable benign export profits will for sure be favorable for export-oriented enterprises to optimize their product structure, improve the technological content of their production, improve their marketing mode and further escalate their competitive capacity. During the thirty years from 1978 to 2008, the average growth rate of export trade in China was approximately $18 \%$, obviously higher than the average growth rate of the global export trade. Export of labor intensive products with obvious cost advantage contributed a lot to growth of foreign trade. It has become an important competitive tactics at present for a large number of export-oriented enterprises to obtain competitive capacity by means of cost advantage, while acquisition of cost advantage can not go without the technical innovation, management innovation and marketing innovation of these enterprises.

\section{Effective tactics for export-oriented enterprises to improve their competitive capacity}

At the Third Session of the Eleventh National People's Congress held in March 2010, the Chinese Premier Wen Jiabao pointed out in his government work report, "We should optimize structure of products exported, stabilize exportation of labor intensive products, enlarge exportation of mechanical and electrical products and high and new technological products, vigorously develop service trade and service outsourcing, try to cultivate export brand and marketing network and continue to strictly control exportation of 'two highs and a capital' products." Thus, in order to optimize the export products, it will have quite important practical significance to guide export-oriented enterprises to further improve their competitive capacity on the basis of cost advantage. In the current post-crisis era, export-oriented enterprises in China should pay close attention to carrying out the following effective tactics.

\subsection{To broaden sales market}

Competition encountered by export-oriented enterprises is not only competition in terms of products, talents and management, but more importantly in terms of markets. The only effective strategy for export-oriented enterprises to alleviate current awkward situation of shut-down or half shut-down in some enterprises is to take an initiative to open emerging markets in Middle East, Africa, Latin America, India and Russia, etc, and domestic markets. Firstly, they should take an active attitude in participating in all kinds of international expo, trade fair and intercommunications, promote their own products in the international market and seek for cooperation partners. Secondly, export-oriented enterprises should initiate domestic markets, set up internal sales network and win domestic markets with good quality of products. Thirdly, if there is no means to open new domestic and overseas markets, export-oriented enterprises may switch to produce new products which have sufficient market potentials and are seldom influenced by the financial crisis. Whether export-oriented enterprises initiate markets with existing products or produce new products with market demand, they have to satisfy the premise of obtaining markets and meeting demands of customers. With markets and customer demand, enterprises can go for product production and carry out cost control strategy to obtain cost advantage. There are quite a large number of export-oriented enterprises with perfect operation performance in Ningbo which ranks after Shanghai and Guangzhou in terms of the scale of foreign trade among the 14 open coastal cities. NINGBO LE'S INDUSTRY CO., LTD. exports not only its products of washing machines overseas, but also the design scheme, blueprint, mould and manufacturing process of its washing machines. Since the year 2008, this corporation has opened markets of Egypt, Russia, Indonesia and Iran, etc, with its mould and technology. After its mould is exported, it is organized for production by local importers who then assembly the spare and accessory parts purchased from this corporation to complete machines for sale. This effectively stimulates exportation of the corporation's spare and accessory parts and further enlarges the space of profits for the corporation.

\subsection{To optimize product design}

Amelioration on products according to value engineering theory and method helps to deeply excavate the potential of reducing cost and to better cope with rise of the price of such elements as raw material and labor force, etc. Amelioration on products according to particular technical requirements and environmental protection requirements helps to effectively withstand overseas technical barrier and green barrier, etc. Firstly, enterprises may ignore unnecessary 
function, appearance and specification to reduce complexity of technical skills and reduce cost of products. Secondly, export-oriented enterprises can also increase appropriate cost to add new functions so as to improve customer value of products and gain their own cost advantage at a new level. For instance, NINGBO HILLARY PANS \& POTS CO., LTD. changes material of pan bottom to make pans usable both on gas stove and induction cooker. Its final cost merely increases by 3\%, whereas its offer of price increases by 30\%. At the 105th Canton Fair in 2009, a Spanish merchant took a fancy to its product and signed at a time an order with the value of $\$ 5$ million. Thirdly, when enterprises ameliorate the design of their products, they can select new material, new technology and new process with lower cost and green environment protection function to gain more cost advantages. For example, Ningbo Beifa Group titled as "China World Writing Instrument Manufacturing Center" develops a series of environmental protection products, including new type of environmental protection material pen, bladder exchanging pen, cotton core gel ink pen with infusion of ink, cassava pen and straw pen, which are all favored by many foreign merchants. Enterprises ought to carry out appropriate differentiation strategies according to their own technical competence and different demands of customers to avoid strategic convergence and cutthroat competition with other enterprises and win favorable market shares with particular products to improve corporate competitive capacity.

\subsection{To strengthen process management}

The process management here mainly refers to management of purchase process, production process and marketing process, specifically coming down to such aspects as purchase management, equipment management, material management, production management, technical management, human resource management, quality management, sales management and financial management, etc, and is closely related with cost management of enterprises and is the top priority to strengthen cost control to obtain cost advantage. At present, a large majority of export-oriented enterprises mainly assume the work of material purchase and products production, while core technology and sales markets with high value added are under control of overseas merchants. Export-oriented enterprises can only explore cost advantages from these two processes, so the situation is quite austere. Thus, when export-oriented enterprises have accumulated enough capital and strength in their role of being agents of production for overseas merchants, they ought to march towards the two high-ends directions of research and development and market pioneering as soon as possible. The major tactics to strengthen process management include the following three aspects. Firstly, export-oriented enterprises should control purchase process in an elaborate way and reduce purchase cost. They may require suppliers to deliver goods or transport goods in due time or pass warehouse of material on to suppliers for management. Enterprises should select high-quality professional purchasing staff, equip unobstructed purchasing information system and employ rational and economic purchasing batch, which all have obvious effects on increase in purchasing effects. Of course, selection of suppliers in local industrial clusters helps to obtain timely, reliable, economic and convenient material supply, which is also an important tactics. Secondly, export-oriented enterprises should organize the process of production in a rational way and reduce production cost. Export-oriented enterprises can confirm the target level of products' cost and carry out cost plan to put into effects according to strategic cost management theory, cost driver theory and target cost management theory from the two perspectives of technical maturity and life cycle of products. Thirdly, export-oriented enterprises can select reliable dealers to reduce loss in payment for goods. Establishment of stable strategic cooperative partner relationship with excellent dealers can not only enlarge the market shares of products and intensify the market competitive force of products, but can also be favorable to control sales expense and loss in receiving payment. For instance, Zhejiang Grand Group Corporation persists in steady operation, sets up the system of separation of the three powers of business management, ownership management and financial supervision, establishes chief financial officer and chief risk control officer, keeps inventory scale and account receivable at a relatively low level by means of making use of advantages in financial integration, human resources, market expansion and strategic decision making and acquires sustainable competitive advantages that others are hardly able to simulate.

\subsection{To reinforce industrial collaboration}

The numerous medium and small export-oriented enterprises are just a tiny boat and are hard to bear attack from changes in international markets. As for major industries, the only way to improve the industrial competitive capacity is to depend on key export-oriented enterprises, strengthen coordination and cooperation with export-oriented enterprises of the same industry and formulate complete industrial cluster. Industrial cluster may lead to economy of scale, economy of scope, division of labor based on high specialization and low-cost transaction expense, which will be important factors to improve competitive force. In 1998, Michael E. Porter in his "Clusters and the New Economics of Competition" pointed out, industrial cluster improved competitive force mainly in the following three aspects. Firstly, enterprises within an industrial cluster exerts influences upon enterprises outside the industrial cluster by means of increasing labor productivity; secondly, enterprises within an industrial cluster lays foundation for development in the future by means of technical innovation in low cost; thirdly, environment of an industrial cluster is favorable for 
generation of new enterprises and enlargement of the scale and influences of the industrial cluster. An industrial cluster can also regard key enterprises as the core to conduct joint stock reform, initiate professional joint company and combine into close industrial complex. Also, an industrial cluster can join strategic alliance with foreign enterprises or merchants to save transaction expense and win sales network with high efficiency. Thus, reinforcement on cooperation and coordination of enterprises within the same industry can not only change the situation of struggling solely and killing each other in enterprises within the same industry, but can also converge power of the enterprises to develop towards the medium and high terminal of value chain. For instance, the upstream and downstream products developed by NINGBO DELI GROUP CO., LTD. have driven development of surrounding medium and small enterprises. Originally, the distribution of export markets of NINGBO TIANHONG STATIONERY CO., LTD. was not wide enough, but after joining in the sales network of DELI GROUP CO., LTD., the market shares of its long tail clip is also enlarged. For the past few years, NINGBO DELI GROUP CO., LTD. has made full use of its extensive sales channel and brand advantage to integrate resources of several hundreds of surrounding medium and small enterprises, which realizes industrial intensification and brand sharing, optimizes connection of industrial chains, reduces consumption of factors and withstands pressure of increase in cost.

\subsection{To attach great importance to innovation in research and development}

On July 11, 2009, at the first summit forum of Chinese enterprises held in Beijing, the well-known Economist Cheng Siwei pointed out in his speech, "With the background of the financial crisis, innovation is the most important and is an important measure to walk out of the crisis. Meanwhile, opportunities for innovation are on the way", and "innovation does not only include technical innovation, but institutional innovation and management innovation should also be emphasized". For the time being, the "bottleneck" which constrains development of export-oriented enterprises mainly lies in weak awareness of independent innovation, serious insufficiency in research and development investment, unfamiliarity with core technology and lack of core competitive force, specifically, low scientific and technical content, low market terminal, low value added and few proprietary brands. $55 \%$ of the total amount of China exports and $90 \%$ of exportation of high and new technical products rely on the trade of processing, which earns merely the scanty expense of processing. In order to change this situation, we have to attach great importance on research and development investment and independent innovation, attempt to transfer from extensive management to intensive management, from labor intensive production to scientific intensive production, from high energy-consuming and high polluting industries to energy conservation and environmental protection industries, from the situation of "made in China" to the situation of "invented in China", and furthermore from lower end of the industrial chain to medium and high end of the industrial chain. Michael E. Porter has ever pointed out, "new technology is the foundation of cost advantage". That is to say, only enterprises with continuous innovation can obtain long-term cost advantage. For example, during the crisis, Haier Group promoted a series of innovative products in production bases in US, Italy, Pakistan, Thailand and India. The three-gate refrigerators designed in Germany and manufactured in Italy were awarded as German Red Dot Design Award and US Industrial Design Excellence Awards. Owing to its design of energy conservation, this kind of Italian style three-gate refrigerator attained European A+ energy conversation standard, and gained British government subsidy worthy of $20 \%$ of its retail price. Research and development innovation has enabled Haier products to obtain competitive advantage that other brands have no means to simulate. The market occupancy rates of several sorts of Haier products have been ranked the top in the world and Haier has become the top brand in global white goods and the most valuable brand in China.

\subsection{To cultivate proprietary brand}

Establishment of proprietary brands in export-oriented enterprises in China has always been weak and among all products exported, the proportion of proprietary brands is even less than $10 \%$. Quite a large majority of garment products are exported without any brand or are original equipment manufacturing, with smaller proportion of proprietary brands. The Economist Li Yining has ever pointed out, "If a product or an enterprise has no advantage in brand, then its competitive threshold is quite low, with bad profits capacity and it will be difficult for it to survive; if an enterprise depends merely on low cost, then it will be difficult to survive, but if it has influences of a brand, then it obtains advantages." For the time being, the situation that export-oriented enterprises are lacking in proprietary brands is extremely out of place with the status of a big power in trade and a big power in export and has greatly restrained development of China towards a great power in trade. Export-oriented enterprises have to attach great importance to establishment of proprietary brands, develop towards the high value added of such industrial chains of research and development and marketing symbolized by proprietary brand and strengthen their profitability. Thus, export-oriented enterprises ought to transfer from "Original Equipment Manufacture (OEM)" to "Original Design Manufacture (ODM), and realize "proprietary brand manufacture" and industrial escalation. The core competitive force of export-oriented enterprises will certainly be greatly increased with sales of proprietary brand, combination with innovation in research and development and resorting to advantages of industrial cluster. The more the profitability, the more the cost 
advantages. For example, in its cooperation with well-known global home appliance brands, NINGBO DAHUA ELECTRIC APPLEANCE CO.,LTD. experienced helplessness in lack of proprietary brand, then it tried every means to create export brand by itself. So far, the company has already registered trademarks in more than ten countries, and is negotiating with a large-scale company in Europe in the hope of promoting its proprietary brand with the help of its sales channel. Furthermore, this company has actively stepped from OEM to ODM and makes an attempt to earn high profits in industrial chains. The way of their cooperation is as below: their partner offers appearance of products or specific requirements, while this company takes responsibility for design of the structure and application of the patent. With successive coming out of a lot of new products with independent design, proprietary export brands and independent intellectual property rights, the international orders of this company have been in an endless stream. Accordingly, its bargaining capacity gets enhanced and its competitive capacity is also further improved.

\subsection{To carry out the walking-out strategy}

From a worldwide perspective, originally, European, American and Japanese enterprises transferred labor intensive manufacturing bases to the Four Little Dragons of Asia with the purpose of obtaining more low-cost natural resources and labor resources. The Four Little Dragons of Asia put forth efforts to develop labor intensive processing industry, so they achieved economic boom within a short period of time. Afterwards, the Four Little Dragons of Asia successfully realized industrial escalation and the cost advantages of their labor intensive manufacturing industry was also gradually lost, so the international manufacturing bases again were transferred to China. At present, India, Vietnam and Pakistan also have more low-cost labor force resources, so they also gradually become the important receivers of transfer of global manufacturing industry. Considering the transfer track, the international manufacturing industry will be rapidly transferred with changes of advantages in natural resources and labor resources so as to gain low-cost resources and produce the most competitive products. Export-oriented enterprises in China should make a grasp of the rule of transfer of international manufacturing industry and carry out the walking-out strategy decidedly in due time. The specific tactics include the following five aspects. Firstly, they should transfer production base to central and western Chinese regions; secondly, they should transfer production base to target countries; thirdly, they should establish cooperative relationship by contract with enterprises in target countries; fourthly, they should carry out the strategy of building overseas sales channel by themselves; fifthly, they should carry out the strategy of cross-border merger and acquisition. In January 2009, Ningbo Oulin Group signed an agreement to initiate companies in Northern Europe with Danish agents with whom it had cooperated for five years. The newly established joint venture company is responsible for sales of Ningbo Oulin Group's cooking utensil products in North European markets. Furthermore, this joint venture company can decide in due time design and production of products in Ningbo Oulin Group according to market demands. This company has jumped out of traditional modes of authorization and agency and has combined into a common destiny together with its agents. By sharing with the joint venture company the international resources of the joint venture partner, this company has lowered its threshold to get access to the international market, which helps to gain long-term competitive advantages.

\section{References}

Communication Department of Ningbo Foreign Trade and Economic Cooperation Bureau. (2009). 30 Tricks of Ningbo Foreign Trade Enterprises to Face with Crisis and Exploit Market.. Ningbo Daily, May 17.

Liu, Ke. (2006). Problems and Countermeasures of Foreign Trade in China. Journal of International Trade, (3):21-25.

Xiao, Wuling. (2006). Characteristics, Problems and Countermeasures of Foreign Trade and Export in Zhejiang Province. Journal of International Trade, (7):89-93.

Zhang, Delin. (2009). Strategic Reflection of Chinese Enterprises in Their Response to the International Financial Crisis. Enterprise Management, (9):12-15.

Zhong, Yihui. (2010). Influences of the Financial Crisis upon Export-oriented Enterprises in China and Their Countermeasures. Journal of Central University of Finance \& Economics, (1):65-70.

Zhou, Weidong. (2009). Influences of the Financial Crisis upon Export-oriented Enterprises in the Yangtze River Delta and Responsive Tactics. Special Zone Economy, (11):51-52. 